\title{
Effects of Relationship Marketing on Customer Retention and Competitive Advantage: A Case Study on Grameen Phone Ltd.
}

\author{
S M Asif Ur Rahman', Muhammad Rehan Masoom²
}

${ }^{1}$ School of Business \& Economics, United International University, Dhaka, Bangladesh

${ }^{2}$ School of Business \& Economics, United International University, Dhaka, Bangladesh

\begin{abstract}
The purpose of this paper is to evaluate whether Relationship Marketing (RM) creates competitive advantage and retains customers for businesses. In order to evaluate RM practices in Grameen Phone (GP), two hundred and sixty five respondents were surveyed. Findings show that GP has been applying RM successfully, consequently retaining customers and achieving competitive advantage. However, GP should emphasize on internal marketing practices and on enhancing employee satisfaction and customer care.
\end{abstract}

Keywords: Relationship Marketing, Grameen Phone, Customer Retention, Competitive Advantage. JEL Classification Code: M31

\section{INTRODUCTION}

TN the world of globalization, telecommunication in1 dustry is one of the fastest growing ventures. Companies in this industry continue to adopt innovative and more sophisticated policies in order to achieve competitive advantages as well as to introduce technological dynamism and provide beneficial services to subscribers worldwide. Grameen Phone, the leading telecom company in Bangladesh, adopted strategies to retain customers with RM. Among different other services, Grameen Phone has committed to providing this most vital service for which the company is mainly chosen by the customers. Essentially, evidences that GP has a reliable network and quality service for its customers contribute to the implementation of RM strategy.

The key component of marketing in the 21st century is to establish relationship between an organization and its customers. Customer service, quality, and marketing correlate with one another (Gillemo et al., 2000). However, organizations have always faced hardships in aligning these concepts together although relationship marketing places great emphasis on customer value rather than simply 'getting the customers' (Christopher et al., 2000). $\mathrm{RM}$ is not a completely new concept rather a paradigm developed over time through overlapping traditional marketing practices.

According to Berry (1983), there are five strategies of relationship marketing that need to be sufficiently developed to create effectiveness in the marketing scheme as shown in Figure-1.

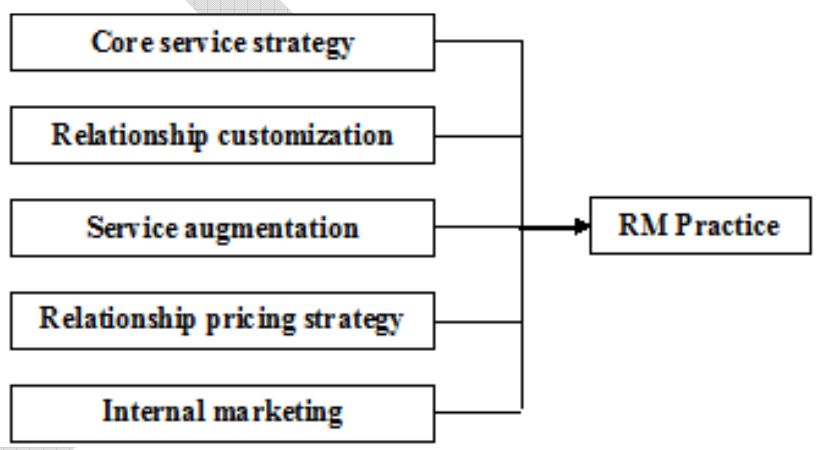

Figure 1: Strategies of Relationship Marketing

Relationship marketing strategy, therefore, suggests that a service provider should know the characteristics and requirements of the individual customer and then should provide the services accordingly (Berry, 1983).

\section{LiteratuRe REVIEW}

$\mathrm{RM}$ is a fundamental sector of marketing that has been discussed among academics and marketing practitioners for over last 20 years. In business management, RM was one of the most controversial factors that were rising to prominence. In fact, it was a unifying force within marketing that "served as the generic context for all marketing transactions, whether products or services, consumer or industrial" (Mattsson, 1997).

Literally, researchers have given different definitions to relationship marketing. However, they mostly possess common denominators. Comprehensively, a definition addresses that relationship marketing identifies, develops, and enhances relationships among all associated 
business personnel along with its customers. Furthermore, it focuses fully on potential profitability and future objectives which can be brought up only by loyal and committed relational exchanges (Egan, 2001). Relationship marketing aims to create relationship with consumers so that they can be satisfied and retained, whereas transactional marketing intends to make the sale and look for new customers (Vence, 2002).

A major shift that is occurring in the conceptual theories of marketing has been stated as a paradigm shift by researchers. The marketing mix and traditional concepts of marketing including services marketing, industrial marketing, and the economy of customer relationship is developing further towards 'relationship oriented approach'. (Grönroos, 1994). This paradigm shift is stated to be Relationship Marketing. There were reasons as to why the need for paradigm shift arose:

- To recognise importance of customer retention

- To globalize the businesses

- To keep pace with progressing market economy

- To develop nature of marketing mix

- To fulfil the need for establishing closer customer relationship

Besides the above market demands, paradigm shift occurred to fulfil the lacking of marketing practices and achievements.

A number of indispensable elements of RM paradigm were discussed where it was mentioned that supplementary knowledge permitted the augmentation of RM as an alternative viewpoint. For instance, the concentration of business was on increasing the number of customers, rather than bringing about retention and satisfaction for customers, although they both share proportional outcome to each other (Schneider, 1980).

Basically, relationship marketing focuses mostly on a longterm relationship with its partners spreading in numerous transactions (Dwyer et al., 1987). This mutually beneficial and long-term characteristic of RM highlights that "customer satisfaction is a necessity but the prominent goal should be to establish a long-lasting relationship on the basis of mutual benefits" (Achrol, 1997). Companies can distinguish the value of long-term relationships with customers and partners, but for implementation they still need proficient knowledge of RM in most cases (Egan, 2001).

\section{Customer Retention}

In relationship marketing customer retention has been given more prominence than mere customer acquisition in perspective of company's benefit and reputation (Gummesson, 1999). More companies accept the theory of customer retention generally because of the following reasons:

- Existing customers are comparatively easier and less expensive to retain than to create new stream of clients.

- It takes much less levels of marketing effort and financial input to satisfy old customers.

- Consumers' loyalty serves as secure and superior profitability over time for the company (Reichheld, 1996; Egan, 2001).

\section{Competitive Advantage in Relationship Marketing}

Service marketing has close linkage with relationship marketing and these two jointly can generate competitive advantage. Telecom industry is basically a service oriented business and it operates on such marketing principles where customer relationship is crucial for profitable business. The fundamental necessity of RM is to attain competitive advantage which generates better economic development. In case of telecom industry, companies should recognize and establish a network of relationship to perform better for its customers (Gummesson 2002; Derozier and Hunt, 2004).

Relationship marketing has the ability to build influential relationships with clientele and with other firms and companies that would result in competitive advantage. On the other hand, 'market relationships create sustainable advantages precisely because they are so difficult to manage'.

From the review of literature the following research questions have been arisen:

1. To what extent relationship marketing is playing a vital role in attracting and retaining customers of Grameen Phone.

2. Has Grameen Phone achieved competitive advantage after implementing relationship marketing?

Conceptual Framework of Relationship Marketing

Appropriate interrelationships of the theoretical concepts of RM are vital to its success. Customer retention and competitive advantage are emphasized in this study which are the basic components of RM achievement. The theoretical framework is presented as below:

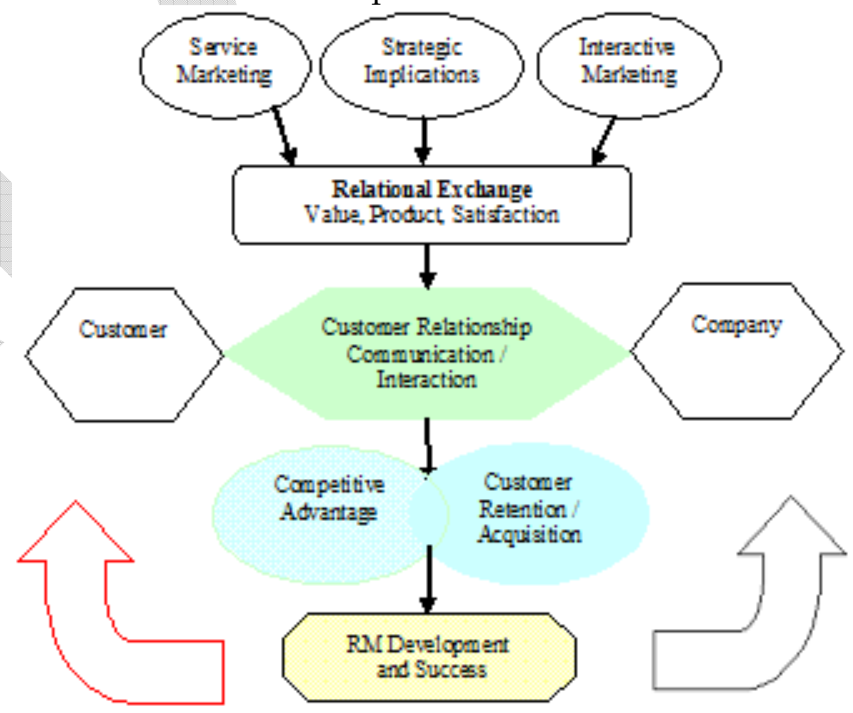

Figure 2: Conceptual Framework of Relationship Marketing Source: Author's analysis based on Literature Review.

\section{ObJective OF THE Study}

The broad objective of the study is to analyze the creation of competitive advantage and customer retention by superior customer relationship marketing of Grameen Phone. The specific objectives are:

1. To investigate internal marketing strategy of Grameen Phone. 
2. To examine the role of customer care in retaining customers.

3. To identify whether GP applies relationship pricing strategy or not.

4. To find out the relationships of GP with distributors and retailers.

\section{Methodology}

The research is exploratory by nature. Grameen Phone was selected as a case since Gummession (1991) states that one case study can be enough if full co-operation is ensured by the sample company. The company was selected on the basis of size, market share, and goodwill of the company. Sample survey was conducted in Dhaka city for this research work. A questionnaire was sent to twenty five GP employees who were responsible for marketing and other departments, from where fifteen respondents replied. First-hand surveys were conducted to collect data from fifty retailers selling mobile phones and providing related services, and the same was also done on 200 general customers, mostly youth population using Grameen Phone mobile service.

A non-probability sampling, specifically snowball sampling was adopted to carry out the survey. In addition to primary data, the paper also utilizes secondary data collected from recognized journals, reports, magazines and websites.

\section{FINDINGS AND INTERPRETATIONS}

At first, different questions of the questionnaire will be discussed, and then the relationship of the company with employees, customers, and distributors will be explained in detail.

\section{Analysis of Findings: Employee Perspective}

Employees responded differently to the same questions. When they were asked about the number of bonus minutes offered to customers for reactivating old SIM cards, $73 \%$ answered 10-12 minutes while rest of them answered either $16-18$ or 19-21 minutes. The most important question was whether GP offers special bonus for customers who are using GP for long time. The answer was, again, surprisingly mixed.

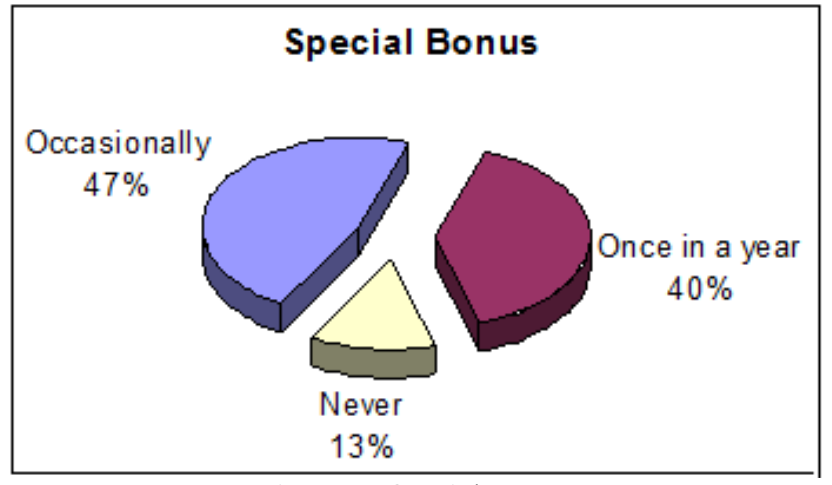

Figure 3: Special Bonus

However, among the employees who replied positively, when they were asked to tell the name of the bonus, they could not answer. Some mentioned "Thank You Bonus", though this particular bonus is given to the customers on the basis of usage; the more one uses the more reward one gets. The next question was asked about the strategy of GP for improving the technology to increase long term relationship. Many of them answered about the increase and improvement of GP network base stations. GP traditionally have attracted and retained their customers through their unparallel network setup. Since in telecommunication sector customers look mostly for consistent and noise-free network, many of the early customers have long stayed with GP in spite of lucrative offers in terms of lower call rate from the other service providers. Therefore, GP seems to be not very interested in using any marketing tools other than strong network system to improve the relationship with the customers. But companies need to bring about holistic change in their marketing and managerial policy when they decide to implement relationship marketing. GP could not change their policy in view of this aspect.

The internal environment is terrifying for the employees in Grameen Phone. Most of them did not answer the questions directly; even they refused to mention their official email address fearing being identified. Some of them did not mention their designation, name and any email address. In their views, company might be trying to create long term relationship through relationship marketing but they never think of keeping good relationship with their employees. No employee wants to execute his/her own plan in any campaign. They witnessed firing of employees who failed to achieve company's objective after implementing their own plan. Employees, especially in marketing department, are uncertain about their job security. As a matter of fact, replies from employees working in marketing department were very limited. Downsizing and abrupt change in hierarchy are the recent policies adopted by the top management. Almost $100 \%$ answers came positively about their network coverage all over the country.

Regarding the company's focus on customers, $67 \%$ replied GP does have that but also they never responded to customers' demand about lowering call rate. They were always follower in this concern. Nearly $54 \%$ said in connection with lowering call rate that high quality deserves high price, and $26 \%$ said high technology cost does not allow them to lower the call rate. One employee pointed out: "GP thinks that the company is providing quality service to its customers. In addition, if you want better service, you should pay more; reducing price will bring you down at same level with the other competitors. GP is still market leader, not a mere follower".

With regard to intention of keeping long term relationship with customers, $80 \%$ employees said Yes and 20\% said No. Though $80 \%$ employees answered positively, there are differences among their satisfaction level. Many of them did not answer to this question. Some even refused to answer as, in their words, it is strictly related with company's strategic issues. 


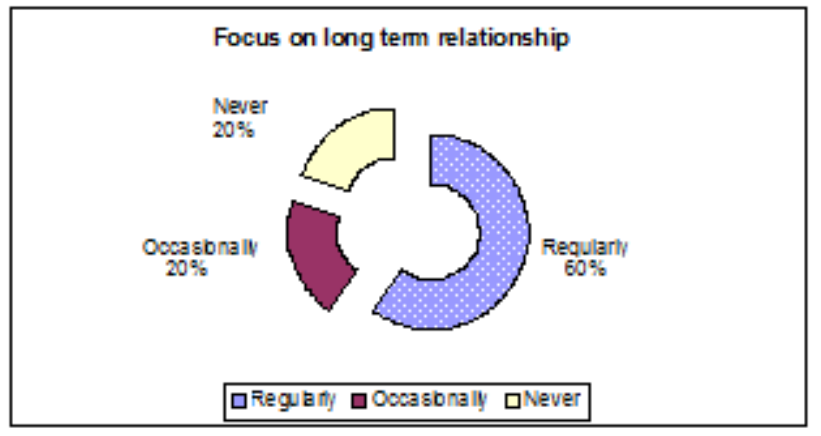

Figure 4: Focus on long term relationship

Figure 4: Focus on long term relationship

GP offered 24 hours customer care service on 7 days-aweek basis before any other operators did the same in Bangladesh. Recently they offered priority day for women. On Tuesdays, if any woman visits GP customer care centre, she will be given priority in service over her male counterparts. A large portion of country's businesspersons are subscribers of GP. Most of them use GP, according to employees, because of best network coverage all over the country, best internet service and best value for money. GP business subscribers are served on regular basis by special bonus. According to the employees "GP introduced a new service named "Bull" through which one will be able to access stock exchange and this will help businesspersons make their life easier." On the basis of usage Company offers Nokia N-series mobile handsets free of cost.

In question of the company helping the poor, some employees reported as occasionally, while some others said regularly and the rest said Never. One of the packages for the villagers is called Polli-Phone, which is the only package for the rural entrepreneurs, especially women.

The need of relationship marketing is surely present for GP and even they are now giving more emphasis on relationship with customers which can be recognized from the customer surveys. In fact, they have taken up a new marketing tag "stay close". Most of their recent advertisements are based on customer care and building and maintaining relationship. Many subscribers had switched from GP to other operators before the company at last went for relationship marketing, and this drop-out number is not less, approximately $2 \%$ in 20 million customers. Nevertheless, 5\% (approximate) customers increased due to RM implementation. All agreed that the reduction in brand-switching was caused by RM application. In question of why the number of GP users is increasing day by day in Bangladesh, 50\% employees reiterated best network and phenomenal brand image. But there are some other reasons that even GP top management could not pick up. According to one employee, "As a customer manager I receive good number of calls from the root level of our country and surprisingly I came to know from my own interest when I asked them why they use GP, most of them answered that using GP is positively related with one's social status". Not only GP but some other operators also started implementing RM and one employee expressed in this words "one day all the other operators will have robust, reliable network. Call charge will also come down. On that time relationship with the customers will differentiate GP with the other competitors".

\section{Findings: Customer Perspective}

GP started their operation in 1997 and brought about a revolutionary change in the country's communication technology, economy, culture and politics. For the first time they introduced pre-paid mobile phone services in Bangladesh. Consequently, most of the early mobile users in the country still remain loyal to GP. This research found almost $63 \%$ GP users are using this network for 3 to 6 years or more. Maximum personal average expenditure in mobile phone is around tk100 to 300 and tk300 to 500 per month. In case of choosing packages, most of them are taking up Smile- a prepaid package. Relatives of most of the GP subscribers' are also using the same operator. Smooth, reliable network is attracting and retaining customer for GP in the first place. A whopping $42 \%$ of respondents used other operator before GP and left those due to network problem. Surprisingly one new point has been highlighted that higher cost of their ex-operator also encouraged them to switch to GP. Therefore, price is the most important factor for choosing mobile service provider in developing countries like Bangladesh. Almost $74 \%$ of the respondents visited GP customer care centre, and among them $67 \%$ are satisfied and $33 \%$ are neither satisfied nor dissatisfied.

\section{Service provided by GP}

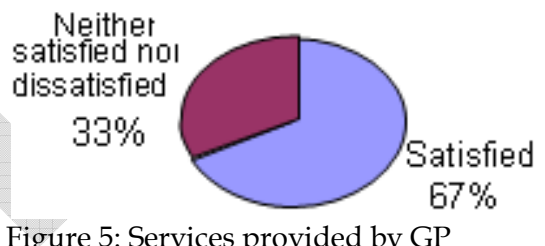

Figure 5: Services provided by GP

Customer manager is a recently created post by GP who is responsible for providing services to the customers. $50 \%$ of the people surveyed are satisfied with the behaviour of customer manager. However, they complained against delay in services. Accountable marketing, one part of relationship marketing, is not practiced by GP properly. Only 39\% customers said that the GP employees call them to know service adequacy. In case of advertisement, there are mixed answers. 30\% customers like advertisement where GP offers bonus talk time or extra facilities for the old SIM card, $24 \%$ are happy with lower call rates in FNF numbers, and 20\% of them spoke highly of bonus talk time. $70 \%$ subscribers encourage their relatives and friends to use GP. This clarifies that customers are satisfied with what GP is offering to them. Only satisfied customers recommend product/ service to others.

One important finding that came up after the survey is that customers keep relationship with GP more for the hazard of brand switching than for GP's relationship marketing. 19\% customers feel the exit barrier, that is, 
they will have to part with a long familiar phone number. In relationship marketing, customers usually deserve an intimate care from the service provider. They want to see the company is remembering them in their special occasions such as birthday, marriage anniversary and so on. GP is trying to fulfil customers' desires but efforts are not very satisfactory yet. $52 \%$ customers said they are not recalled on their special occasions. To build and maintain relationship, company can offer a lot of services. According to the customers, Thank You bonus and free texts messages are company's only relationship tools. One objective of relationship marketing is to make the customers loyal to the company and retain them without any cognitive dissonance. When customers were asked "how long will you be with GP?", 43\% said they will keep up with GP for their lifetime, 23\% said 7 years and 32\% mentioned 5 years. Customers said they want to keep long term relationship with GP but the company will have to reduce the tariff and increase quantity of FNF (friends and family) numbers.

In case of loyalty, approximately $74 \%$ customers said they consider themselves loyal customers of GP. Customers are very much inclined to have relationship with GP but the company didn't do anything in respect of customer's demand and preferences. Almost $74 \%$ customers showed their discontent in that the company is not offering any extra facilities to those who are using Grameen Phone from the very beginning. This is an issue to be concerned about from the perspective of RM after 15 years of service. $18 \%$ respondents replied negatively about the question "Grameen Phone gives more emphasis on retaining existing customers rather than attracting new ones." Almost $61 \%$ customers agreed with this statement. Approximately $45 \%$ customers will stay with the company in spite of better/cheaper offer from other operators. This indicates the result of some good practices of relationship marketing by GP. It has created an atmosphere of loyalty inside and outside the firm. 58\% people said that in future they will use GP more often.

In case of communicating in remote areas, almost $75 \%$ told they always use GP. Relationship can be measured by the emotion of customers with particular product. Almost $50 \%$ customers agreed they consider GP as one of their family members. But $25 \%$ are still ready to say negative to other about the company. Relationship with GP is pleasant and worthy to $66 \%$ customers.

Customers showed their discontent where GP offers lucrative benefits to attract new customers only rather than to retain the old ones. The socially established brand image encouraged customers to use GP for a long time and 57\% of the respondents told it has become part of their identity. In this case GP is successful in relationship marketing.

\section{Findings: Distributor Perspective:}

There are different types of distributors or retailers. Some directly sell SIM cards, balance recharge cards, mobile phone handsets, accessories etc, while some others buy mobile connections from GP on business purpose and sell talk times to customers most of whom cannot afford their own mobile phone. Most of the retailers were found doing business with GP for a long time. Almost 30\% told they were doing business with GP for 4 years and 28\% for more than 5 years, rest of them for 1,2 or 3 years.

When the question was asked whether "GP employees keep good relationship with the distributors", most of the answers were positive or neutral.

GP employees keep good relationship with distributors

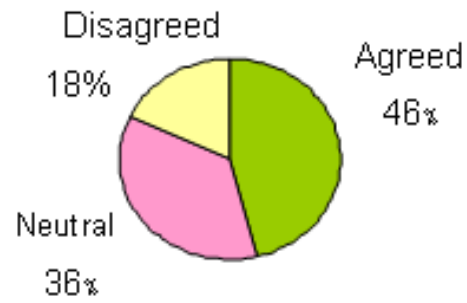

Figure 8: GP employees keep good relationship with distributors

GP fulfils their requirement promptly and in the manner the distributors like. 52\% GP employees, as this research finds out, behave in courteous and friendly manner, while $60 \%$ said they were professional in interaction with the distributors. On the other hand, distributors face difficulties when GP offers new package or new call rate. Most of the distributors are less educated, hence they face problem in explaining these changes to the customers. It is a matter of regret that $58 \%$ distributors said GP employees could not properly explain changes in time. GP is always late to pay heed to the distributors, which sometimes frustrate the distributors and force them to think about switching their business over to other operators. In comparison to other operators, GP distributors are happy with GP services.

\section{Conclusion And Recommendations}

Relationship marketing is the key to business success, specifically in industries like telecom services. Nowadays, companies are putting more emphasis on customer care and long-term relationship than on anything else and so does Grameen Phone too. GP has changed their slogan to "Stay Close" whereas Banglalink says, "We Promise", and City cell says, "We Care" -all of which point out strong competitive environment within telecom industry in Bangladesh. GP is applying customer relationship marketing to attract and retain customers, and to achieve competitive advantage. It takes a lifetime to build and maintain a strong, reliable, trustworthy relationship but needs only moments to shatter everything down. It is a fragile bondage with the customers with whom marketers usually don't have any blood relation yet it is the crucial most things for the survival and growth of businesses. GP has also experienced some gap in their performance and customer expectations. It is high time to rectify all the problems and minimize the gap as much as possible. 
Here we recommend some opportunities GP could capitalize on:

- Lack of internal marketing generating from dissatisfied employees is one of the indispensable factors that company needs to resolve.

- Grameen Phone should immediately create a friendly and motivating environment for its employees because they are the second most vital structural element for the company besides its customers. It is important to secure employees' job other than firing them for their adventurous mistake. Company should share responsibility of unsuccessful campaigns made by employees.

- Since large number of the distributors and retailers are uneducated, they cannot understand every change made by the company in terms of packages, tariff etc. In order to make distributors more efficient, company needs to start appointing proficient, skilled distributors and also to set up specialized training programs for them.

- Continuous customer care depends on continuous employee development. Hence, the company should train their employees on a regular basis.

- Some certain group of customers, especially business people and the affluent segment of our society, look at price as a reflection of quality and status. GP charges higher tariff than other operators but still customers are with them. This finding signifies that company need not reduce its price significantly right now as many of the customers relate it with their status.

- GP should maintain a well balanced management. It should also convince general people about their contributions in the economy and well fare of the country.

As of January 2012, GP is the current market leader in Bangladeshi telecommunication industry; but no position in business is secured for good. CityCell, who pioneered this industry in this country, are in the 4th position now. Competition is becoming fiercer and all the companies are now focusing on RM rather than only on transactional marketing. For GP's further growth, recommendations discussed in this section should be implemented. GP is well ahead of their competitors but this gap is becoming narrower day by day which they need to pay careful heed to. Once the market will be saturated and all will try to win their competitors' customers. GP should not forget that though customers have stayed with them for a long time, they are always benefit oriented and are becoming ever more demanding. Slight lag in relationship might deteriorate the hard-earned positioning of the company. Therefore, there is no chance to be delighted rather Grameen Phone should go searching for the excellence always.

\section{REFERENCES}

[1] Achrol, R. S., 1997, "Changes in the theory of inter-organisational relations in marketing: towards a network paradigm," Journal of the Academy of Marketing Science, Vol. No. 25, January, pp. 56-71.

[2] Berry, L.L., Shostock, G.L., and Upah, G.D. (Eds), 1983, “Emerging Perspectives on Services Marketing", American Marketing Association, Chicago, IL, pp. 25-8.

[3] Christopher, M. Payne, A. and Ballantyne, D., 1991, Relationship Marketing. London:

[4] Hunt, S.D. and Derozier, C.,2004 "The normative imperatives of business and marketing strategy: grounding strategy in resourceadvantage theory", Journal of Business \& Industrial Marketing Vol. No. 19, January, pp. 66-82.

[5] Dwyer, F.R., Schurr, P.H., and Oh, S., 1987, “Developing Buyer-Seller Relationships,",Journal of Marketing, Vol. No. 51, July, pp. 11-27.

[6] Egan, J.2001, “Relationship Marketing Exploring relational strategies in marketing". England: Prentice Hall.

[7] Gillemo, S. and Rijksen, M.,2000, "SAAB versus Internal Marketing. Unpublished Masters Thesis," Goteborg University.

[8] Grönroos, C.,1994, "From Marketing mix to Relationship marketing: Towards a Paradigm Shift in Marketing," Management Decision Vol. No.32, July, pp 4-20.

[9] Gummession, E., 1991, "Qualitative Methods in Management Research,"London: Sage Publication.

[10] Gummesson, E.,1999,“'Total Relationship marketing; Rethinking Marketing management from 4Ps to 30Rs," Oxford Publication: Butterworth Heinemann.

[11] Gummesson, E., 2002, "Practical Value of Adequate Marketing Management Theory", European Journal of Marketing, Vol. No.36, October, pp 325-49.

[12] http://www.btrc.org.bd/ [30 August 2008]

[13] http://www.grameenphone.com/index.php?id=63> [30 August 2008]

[14] Mattson, L.G., 1997, "Relationship marketing and the markets-asnetworks approach: a comparative analysis of two evolving streams of research," Journal of Marketing Management, Vol. No.13, October, pp. $447-61$.

[15] Reichheld, F.F., 1996, “The Loyalty Effect: The Hidden Force Behind Growth, Profits and Lasting Value," Boston, MA: Harvard Business School Publications.

[16] Schneider, B.,1980, "The service organization: climate is crucial," Organizational Dynamics, Vol. No. 9, July, pp. 52-65.

[17] Vence, D., 2002, "It's still the master key - marketers always will rely on transactional angle," Business Source Premier, Vol. No. 36, No. January, pp.1-9. 